\title{
Incidence of Milk Fever on Dairy Cows and Its Risk Factors in Gondar Town, Northwest Ethiopia
}

\author{
Anteneh $\mathrm{S}^{1}$, Guadu $\mathrm{T}^{1}$, Fentahun $\mathrm{T}^{2 *}$ and Chanie $\mathrm{M}^{3}$ \\ ${ }^{1}$ University of Gondar, Faculty of Veterinary Medicine, Unit of Veterinary Epdemiology and Public Health, \\ Ethiopia; ${ }^{2}$ University of Gondar, Faculty of Veterinary Medicine, Unit of Basic Veterinary Sciences, Ethiopia; \\ ${ }^{3}$ University of Gondar, Faculty of Veterinary Medicine, Unit of Veterinary Paraclinical Studies, Ethiopia.
}

[Received: January 8, Accepted: October 28, 2012]

\begin{abstract}
The study was conducted on 384 dairy cows in Gondar town during October, 2009 to January, 2010 to determine the prevalence of milk fever and risk factors associated with the disease. Data was collected using regular farm visits, clinical examination of periparturient cows and response to treatment. The overall prevalence of milk fever was $30.2 \%$. Milk fever was significantly associated with milk yield $(\mathrm{p}<0.05)$, parity $(\mathrm{p}<0.05)$ and breed $(\mathrm{p}<0.05)$. Cows with $<25,25-30$ and $>30$ liters of milk per day per cow had $21.83 \%, 22.4 \%$ and $50.92 \%$ milk fever respectively. The occurrence of milk fever was $17 \%, 17 \%$ and $73.3 \%$ in cows with $<3,3-4$ and $\geq$ parities. The prevalence was higher $(\mathrm{p}<0.05)$ in $>50 \%$ Friesian blood and $50 \%$ Friesian blood cows. Seventy five percent of the cows showed variable response to treatment with Calcium borogluconate, $16.37 \%$ did not respond and died and the remaining $8.62 \%$ of cows died due to lack of treatment. From these results, milk fever appear to be a big problem in Gondar dairy farms while milk yield, parity and breed are the associated risk factors for the occurrence of milk fever. Therefore, dairy farm owners should be aware of the disease and prepare themselves how to manage peripartum intake of calcium.
\end{abstract}

Key words: Gondar town, Milk fever, Prevalence, Dairy Cows, Calcium borogluconate

\section{INTRODUCTION}

Amongst domestic farm animals the metabolic diseases achieve their greatest importance in dairy cows. The high producing dairy cows always verge on abnormality because the breeding and feeding of dairy cattle for high milk yield is etiologically related to the diseases of metabolism so common in these animals. In dairy cows, the incidence of metabolic diseases is highest in the period commencing at calving and extending until the peak of lactation is reached, and this susceptibility appears to be related to the extremely high turnover of fluids, salts and soluble organic materials during the early part of lection ${ }^{[1]}$.

Milk fever, also known as parturient paresis which results from severe hypocalcaemia, is one of the metabolic diseases occurring most commonly in adult cows within 48 hours after parturition, but it may occur several weeks before or after parturition. Clinically it is characterized by hypocalcaemia ${ }^{[2,3]}$. Milk fever is estimated to occur at the rate of 5-10\% in USA and the economic loss for treatment and loss in milk production was estimated at 334 USD per occurrence ${ }^{[4]}$. Cows that recover from milk fever are less productive and more susceptible to other health disorders such as ketosis, mastitis, Retained Fetal Membrane (RFM), displaced abomasums and uterine prolepses'. Besides, most of untreated cows with milk fever die within a day.

The risk factors for hypocalcaemia could be grouped into intrinsic risk factors, which are associated within the animal itself, and extrinsic risk factors, which are outside of the animal's body ${ }^{[5]}$. Serum calcium level falls in adult cows at calving due to the onset of lactation. There is a genetic predisposition of cows to milk fever and this is well recognized in certain breeds of high producing Jersey and other breeds ${ }^{[6,}$ 7].

Diets high in phosphorus (>80gm/day) at the onset of lactation also increase the incidence of milk fever and the severity of hypocalcaemia. High dietary level of phosphorus decreases the production of 1,25 $(\mathrm{OH})_{2}$ Vitamin $\mathrm{D}_{3}$ and thus reduce the intestinal calcium absorption mechanisms ${ }^{[8]}$. Recent Studies indicate that the anion-cation balance in prepartum diet may be more than the level of dietary calcium as a risk factor of milk fever ${ }^{[6,9]}$. Pre-partum diets high in cations like sodium and potassium are associated with an increased incidence of milk fever while diets of high in anion, especially chlorides and sulfur are associated with decreased incidence of the disease ${ }^{[2,}$ 3].

Although milk fever was known to occur sporadically in dairy cows, it appears recently that the frequency has dramatically increased in Gondar small holder dairy farms. However, there has been no study on the extent of the disease and factors that influence its occurrence. Furthermore, the occurrence of milk fever made me to fell from my deepest heart especially among highly productive dairy cows in milk yield. These were the points which initiated the research to be done on the topic of milk fever. Therefore, the main objectives of this study were to determine the prevalence rate of milk fever in 
Gondar dairy farms and to identify and indicate the possible risk factors of the disease.

\section{MATERIALS AND METHODS}

\section{Study Area}

The study was conducted at Gondar, the capital of North Gondar administrative zone of Amhara regional state, which is located $710 \mathrm{~km}$ North West of Addis Ababa. The study area has an altitude of 1850 masl. The average annual rainfall was $850 \mathrm{~mm}$. The minimum and maximum temperature averages were 8.9 and $26^{\circ} \mathrm{c}$, respectively. The average relative humidity was $58 \%{ }^{[10]}$.

\section{Study Design}

Based on cross-sectional descriptive survey was the design of the study to determine the prevalence of milk fever and its risk factors that predisposes to milk fever.

Table 1. Percentage of milk fever in cows with different milk yield groups in Gondar town, December 2009. visiting farms when dairy owners made calls or came to FVM to get a veterinary service for cows that fall with hours after calving. Clinical examination of the comatosed and recumbent cows, the condition of the cows, signs and symptoms manifested and other relevant information associated with the disease were recorded.

\section{Therapeutic Responses}

A follow up study was made on those clinically diagnosed milk fever cases after treatment with calcium borogluconate. Rapid responses, failure to therapy or reoccurrence also were recorded.

\section{Data Analysis}

The data was presented using the descriptive statistics. The association between milk fever and risk factors such as breed, parity and milk yield etc were analyzed using chi square $\left(\chi^{2}\right)$ test.

\section{RESULTS}

\section{Survey Results}

A study was conducted on 51 farms with a total of 384 cows whose owners were willing to cooperate.

\begin{tabular}{cccc}
\hline $\begin{array}{c}\text { Milk yield per day } \\
\text { (liter) }\end{array}$ & No. of cows & No. of positive cows & Percentage of milk fever \\
\hline$<25$ & 142 & 31 & 21.83 \\
$25-30$ & 134 & 30 & 22.4 \\
$>30$ & 108 & 55 & 50.92 \\
\hline Total & $\mathbf{3 8 4}$ & $\mathbf{1 1 6}$ & $\mathbf{3 0 . 2}$ \\
\hline
\end{tabular}

$\chi^{2}$ calculated $=30.597, \mathrm{p}<0.05$

\section{Study Animals and their Management}

This study was conducted on privately owned dairy cows in Gondar town and those of nearby peasant farmers associations during Oct.2009 - January 2010. The study included a total of 384 cows of two breeds i.e. cows with $50 \%$ Friesian blood and those with > $50 \%$ Friesian blood. In Gondar town cows were managed intensively where animals were housed and watering and feeding takes place indoor. The animals were fed on diets containing hay, wheat bran, and crop residue and/or oil seed cakes. The management in some peasant's farm building was somewhat semiintensive where animals were housed at night and until $12.00 \mathrm{am}$ and grazed during the day until 4.00 pm.

\section{Questionnaire Survey}

Information was collected by regular farm visits and using pre-designed questionnaires regarding the animals housing, feeding, reproductive traits, breeds, milk yield, time of occurrence the disease with respect to parturition etc.

\section{Clinical Observation and Examination}

Regular Farm visits were made to the dairy farms in Gondar town and the farmers association around Gondar to follow up periparturient cows and subsequent occurrence of milk fever. Also, milk fever cases were obtained and followed up by
Among these some owners needed veterinary services from FVM for the treatment of cows with milk fever. Using this opportunity, the farms were included in the study to make a case follow up study. Overall the prevalence of milk fever was $30.2 \%$. In Gander town there were a few farms having more than 5 cows owned by private owners. Most urban dwellers keep 5 or less number of cows for milk production and replacement of the lactating cows. The result of questionnaire survey and farm visits showed that most of the cows affected by milk fever were house fed supplemented with concentrates (oil seed cakes and wheat bran).

Mostly the cows affected with the disease had good body condition score and were housed in separate concrete pens. The diary farm owners did not know very well about the nutrient composition of the various feeds such as noug seed cake, linseed cake and white bran. The owners simply mix oil seed cakes and wheat bran with brewery by-product and feed the animals. Water was available for the animals adlib, and mineral lick was provided in a very few farms occasionally.

There was a strong association $(\mathrm{P}<0.05)$ between milk fever and parity. High prevalence of milk fever was observed in cows with as parity increases (Table 2). The occurrence of milk fever in relation to number of calving, milk yield and breed of the cows and time of occurrence (before and after calving) has 
been examined. Table 1 showed that the relative occurrence of milk fever in association with milk yield per day. Similarly, Table 2 and 3 shows the percentage of milk fever in relation to parity and breeds respectively.

Table 2. Percentage of milk fever in cows with different parity in Gondar town, December 2009. the incidence of milk fever increases above $10 \%$ in their third or latter lactation, considerations should be given to a specific control program ${ }^{[5,11]}$. Therefore, these results indicated that control methods are required to avoid loss due to milk fever.

Milk fever is caused by a severe deficiency of metabolizable calcium ion in the circulation ${ }^{[12]}$. This could be attributed due to several risk factors. The risk factors identified in this study include milk

\begin{tabular}{cccc}
\hline Parity & No. of cows & No. of positive cows & Percentage of milk fever \\
\hline$<3$ & 147 & 25 & 17.0 \\
$3-4$ & 147 & 25 & 17.0 \\
$\geq 5$ & 90 & 66 & 73.3 \\
\hline Total & $\mathbf{3 8 4}$ & $\mathbf{1 1 6}$ & $\mathbf{3 0 . 2}$ \\
\hline
\end{tabular}

$\chi^{2}$ calculated $=103.693, \mathrm{P}<0.05$

This study showed that all cases of milk fever in Gondar dairy cows within 72 hours after parturition. The occurrence of milk fever was significantly associated $(\mathrm{p}<0.05)$ with milk yield (Table 1$)$. It was higher in cows producing more than 30 liters of milk per day. There was also a significant relationship between milk fever and parity $(\mathrm{p}<0.05)$ and breed $(\mathrm{p}<0.05)$. Cows with 50\% Friesian blood had higher prevalence than those with $>50 \%$ Friesian blood.

\section{Therapeutic Responses}

From a total of 116 cows affected with milk fever 87 $(75 \%)$ of them showed variable response to therapy. Of these 55 cows $(63.2 \%)$ showed rapid responses to a single bottle of calcium borogluconate $(400 \mathrm{ml}, 1 \%)$ and the rest $32(36.8 \%)$ cows had relapse after first therapy and additional dosage was needed for 3 successive days. From these, $19(16.4 \%)$ cows of the cases failed to show responses and all of them died due to aspiration pneumonia. However, 10 (8.62\%) cows died from lack of treatment because calcium borogluconate was not available on market during the ailment.

Table 3. Percentage of milk fever in different breeds of cows in Gondar town, December 2009. yield, parity, and breed of the cows. The occurrence of milk fever was significantly associated with milk yield. From these results milk yield appeared to be an important risk factor because from a total of 116 cows affected with milk fever 55 (50.92\%) were producing $\geq 30$ liters of milk per day. This study also showed that all cases of milk fever in Gondar dairy cows occurred within 72 hours after parturition. Also, increased prevalence rate is associated with increased number of calving, and hence parity is another risk factor for milk fever. From local breeds only $6(15 \%)$ had milk fever and from which 110 $(31.9 \%)$ cross breed cows had the disease and this shows that cross breed cows are more susceptible to milk fever than local breeds. This could be attributed to high milk yield and low ability to maintain calcium homeostasis in cross breed cows compared with local breeds. Serum calcium level falls in all adult cows at calving due to the onset of lactation ${ }^{[8]}$. Within a breed, the level of fall may be more in some cows than in others and it is this difference, which results in the varying susceptibility of animals to milk fever.

Almost all cows with milk fever were kept in-door with zero grazing. They were provided with concentrate feeds consisting of oil seed cakes (Lin seed cake and noug seed cake), Wheat bran, and teff straw and barely straw. All cows which responded to treatment with calcium borogluconate were variable

\begin{tabular}{cccc}
\hline Parity & No. of cows & No. of positive cows & Percentage of milk fever \\
\hline $50 \%$ Friesians & 40 & 6 & 15 \\
$>50 \%$ Friesian & 344 & 110 & 31.9 \\
\hline Total & $\mathbf{3 8 4}$ & $\mathbf{1 1 6}$ & $\mathbf{3 0 . 2}$ \\
\hline$\chi^{2}$ calculated $=11.223, \mathrm{p}<0.05$ & & $\begin{array}{l}\text { with some relapses that required treatment for three } \\
\text { successive days. All untreated cows died within two } \\
\text { days after the onset of clinical signs. }\end{array}$ \\
DISCUSSION &
\end{tabular}

This study showed that the prevalence of milk fever was $30.2 \%$ in a total of 384 milking cows in Gondar dairy farms. Most of the literatures suggest that when

\section{CONCLUSION AND RECOMMENDATIONS}


In conclusion, the study result shows that milk fever is one of the major disease problems in Gondar dairy farms. Milk yield, parity and breed of cows are some of the factors which contribute to the occurrence of milk fever on the study area. Having the above conclusions, the following recommendations are forwarded: Availability of the drug (calcium borogluconate) to treat the case should be insured among the expected governmental and nongovernmental veterinary health clinics throughout the year. The owners of dairy farms and private animal owners should be aware of the disease and prepare themselves how to manage peripartum intake of calcium. Government officials of the respective sector in the town should give attention to milk fever and should make the drugs (e.g. calcium borogluconate, calcium oral gel etc.) available in the market at reasonable costs.

\section{REFERNCES}

1. Erb HN and Corohn YT (1988). Epidemiology of metabolic disorder in the parturient dairy cows. Journal of Dairy Science. 9 (7): 2557.

2. Kaneko JJ (1989). Calcium regulatory hormone and abnormal mineral Metabolism. Clinical Biochemistry of Domestic Animals. Fourth edition, USA, Academic press. pp: 699-752.

3. Smith J, Cotcott EJ (1969). Metabolic and Endocrine disease progress in cattle and sheep practice. Part III, USA, American Veterinary Publication, pp: 115.

4. Bushinsky DA (1996). Metabolic alkalosis decreases bone calcium efflux by suppressing osteoclasts and stimulating
Osteoblasts. American Journal of Physiology. 271:216-222.

5. Peterson AB and Beede DK (2002). Periparturient responses of Multiparous Holstein cows to varying prepartum dietary phosphorus. Journal of Dairy Science. 85 (1):187-189.

6. Colls GE (1980). Parturient paresis. Veterinary Clinical Pathology, Third edition, USA, W.B. Saunder Co., p: 305.

7. Hunting W (1964). Recent advances in our knowledge of milk fever, The Veterinary record. The British Veterinary Association, pp: 1275-1278.

8. Horst RL (1986). Regulation of calcium and Phosphorus homeostasis in dairy cows. Journal of Dairy Science. 69: 604-605.

9. Brandly GA and Cornelius CE (1971). Parturient Hypocalcaemia in Dairy Cows. Advances in veterinary science and comparative medicine. Vol. 15, USA, Academic press, pp: 143-150.

10. Hunger TG (1975). Milk fever. Disease of Livestock, Eighth edition, Austria, MC Grawil book company, pp: 260-261.

11. NMSAE, 2005. National Meteorology Service Agency of Ethiopia, 2004-2005 Annual report.

12. Radostitis OM, Blood, DC, Gay, CC (2007). Parturient paresis. Text book of the disease of cattle, sheep, pig, goats and horses, Eighth edition, UK, Billiere Tindall, pp: 1314- 1317. 